\title{
Mapping symbolic (anti-) consumption
}

\author{
Margaret K. Hogg *, Emma N. Banister, Christopher A. Stephenson \\ Department of Marketing Lancaster University Management School, Lancaster LA1 4YX, United Kingdom
}

Received 1 June 2007; received in revised form 1 November 2007; accepted 1 January 2008

\begin{abstract}
Rejection is at the heart of anti-consumption and is therefore key to some of the central relationships in symbolic consumption. However, researchers find rejection difficult to study because of the lack of material traces. This article draws on earlier frameworks to develop a new integrated and expanded conceptualization in order to achieve a more nuanced view of how rejection operates within symbolic consumption; and also to initiate research directions for investigating and theorizing rejection in anti-consumption. The focus on anti-consumption incorporates the interaction between avoidance, aversion and abandonment, and the relationship between distastes and the undesired self (mediated by the marketing, social and individual environments). A series of interrelationships and illustrations suggest how the expanded conceptualization is useful for theorizing and investigating anti-consumption.

Crown Copyright (C) 2008 Published by Elsevier Inc. All rights reserved.
\end{abstract}

Keywords: Anti-consumption; Negation; Rejection; Distastes; Undesired self; Aversion; Avoidance; Abandonment

\section{Introduction}

Rejection is at the heart of anti-consumption (Lee, 2006; Lee et al., 2009-this issue; see also Fournier, 1998a; Wilk, 1994, 1995 , 1997) within symbolic consumption. Symbolic consumption involves reciprocal and reflexive relationships between products (tastes and distastes) and consumers (positive and negative selves) within their social contexts. Bourdieu (1984) argues that in order to understand tastes researchers need to identify and appreciate the central role of distastes. Ogilvie's (1987) argument that "without a tangible, undesired self, the real self would lose its navigational cues" (p. 380) further clarifies the series of reciprocal relationships within symbolic consumption. However, despite the central importance of the dialectic between the undesired self (Ogilvie, 1987) and distastes (Bourdieu, 1984) for both academic and managerial understanding of rejection, this inter-relationship remains one of the most neglected and under-theorized areas in consumer behavior research. While this theoretical and empirical gap

\footnotetext{
* Corresponding author. Fax: +44 1524593928.

E-mail addresses: m.hogg@lancaster.ac.uk (M.K. Hogg), e.banister@lancaster.ac.uk (E.N. Banister), chrisstephenson1000@hotmail.com (C.A. Stephenson).
}

persists, the ability to understand how rejection mediates consumer-product interactions within symbolic consumption remains strictly limited.

This article presents a new expanded conceptualization, integrating two earlier frameworks (Ligas and Cotte, 1999, p. 611; Banister and Hogg, 2004, p. 856) in order to achieve a more nuanced view of how rejection operates within symbolic consumption; to initiate research directions for investigating and theorizing rejection in anti-consumption; and to contribute to debates on the role of rejection and anti-consumption within symbolic consumption.

A literature review informs this expanded integrative conceptualization. Two sets of inter-relationships illustrate the generative potential of the new framework specifically for anticonsumption. Directions for future research encompass a number of different levels (super-ordinate, middle and subordinate), with links to wider issues in consumer research, and implications for theory, research, methods and practice.

\section{Literature review}

This article responds to Sirgy's argument (1982, p. 294) concerning the lack of theory in earlier studies of the key 
relationships in symbolic consumption (e.g. self-concept studies in consumer behavior; self-image/product-image congruency models). The literature review draws on a range of concepts and theories including symbolic interactionism and self-reflexivity; social identity theory including accentuation and stereotypes; the motivational effects of possible selves (Markus and Nurius, 1986) and the undesired self; and image congruency. The overall aim is to use these self-group theories from social psychology to provide a richer theoretical underpinning for the key components and inter-relationships in symbolic consumption-and thus in anti-consumption-as-rejection-represented by the expanded conceptualization presented here.

\subsection{Symbolic interactionism and social identity theory}

Self-reflexivity (from symbolic interactionism) and accentuation (from social identity theory) are central to understanding the inter-relationships between individuals and groups, and therefore provide an effective starting point for understanding the inter-relationships between consumers, products and audiences. Self-reflexivity recognizes the capacity of individuals to take "the perspective of the other" (Mead in Dittmar, 1992, p. 75) in relation to the self (or "me", Mead, 1934) and the role of "socially shared meaning systems" (Dittmar, 1992, p. 75). However, individuals function with regard to a range of selves. As Ligas and Cotte (1999) illustrate, symbolic interactionism provides a valuable basis for examining possible selves (Markus and Nurius, 1986) and consumption.

Social identity theorists argue that "social groups are inevitable because ...they fulfill individual and societal needs for order, structure, simplification, predictability and so forth..." (Hogg and Abrams, 1998, p. 18). Using the principle of accentuation from social identity theory (e.g. Hogg and Abrams, 1998; Tajfel, 1981) helps us understand the process of interpretation which consumers use to classify themselves (and by association, endorse or reject products and services) in relation to in-groups and out-groups. These different groups represent the co-ordinates (Simmel, 1955, p. 140) that individuals use to denote their positioning vis-à-vis others via symbolic (anti-) consumption.

Most consumer research examines the use of consumption to denote membership of in-groups (e.g. subcultures of consumption, Schouten and McAlexander, 1995; brand communities, Muniz and O'Guinn, 2001); and the social meanings that individuals derive from their group membership and relationships with brands (e.g. Fournier, 1998b). Researchers pay rather less attention to the use of anti-consumption to signal membership of in-groups; or to the role of dissociative (White and Dahl, 2006) or out-groups. One particular concern is with the groups from which consumers aim to disassociate themselves, as these represent the navigational cues for the undesired selves that individuals use to position themselves in articulating anticonsumption-as-rejection. Avoidance out-groups display feelings ranging from indifference (e.g. just not me, Banister and Hogg, 2001) to negativity and hostility (e.g., undesired self, Ogilvie, 1987). Avoidance groups thus function as negative anchors for consumers (Englis and Solomon, 1995) or co-ordinates (Simmel,
1955) and link to Ogilvie's (1987) undesired selves. Applying disidentification theory (Elsbach and Bhattacharya, 2001) suggests that consumers have clearer views of their 'undesired selves' than of avoidance groups. In-group members not only perceive out-group members as possessing less desirable traits, but also see them as more homogeneous as well (see Brewer and Kramer, 1985; Haslam et al., 1996; Hilton and von Hippel, 1996). People tend to know more in-group members, and therefore are able to perceive them as heterogeneous, noticing subtle differences. Negative stereotypes associated with avoidance groups (Hogg and Abrams, 1998, p. 21) are particularly powerful. Individuals also practice self-stereotyping, where they perceive themselves to be a member of a group and consequently behave in line with this social identity (Biernat et al., 1996). The expanded conceptualization represents the formation and maintenance of both positive and negative stereotypes through a variety of cognitive and motivational processes, and the resulting impact on (anti-) consumption.

\subsection{Possible selves and the undesired self}

Previous research (Kleine et al., 1993) challenges the notion of a global self and argues for a multi-layered or multi-dimensional self within the context of symbolic consumption. Possible selves incorporate this view of the self as a dynamic structure involving a multiplicity of selves (Cantor et al., 1986) with either positive or negative end states. These selves provide consumers with goals, aspirations, motives, fears and threats as well as with the selfrelevant information that individuals need to organize and give direction to their lives (Markus and Nurius, 1986). Possible selves provide an evaluative context for the current view of the self, motivating people to approach desirable possible selves while also avoiding undesirable ones. Negative or rejected possible selves, therefore, function as (dis)incentives for future behavior, representing selves to reject or avoid (Markus and Nurius, 1986). Various aspects of negative and rejected selves provide important reference points or navigational cues for individuals to assess how close or distant they are from being like their most negative images of themselves (Buchanan-Oliver, 2006; Eisenstadt and Leippe, 1994; Ogilvie, 1987).

An individual's undesired self(Ogilvie, 1987) is of particular relevance here because anti-consumption-as-rejection (within symbolic consumption) is about what a person is afraid of becoming, and involves a strong motivational drive to protect self-esteem. Motivational factors lead to the rapid confirmation yet the slow or begrudging disconfirmation of a negative expectancy (Hilton and von Hippel, 1996). Marketing managers recognize the pursuit or protection of self-esteem as one of the most important motivational drivers of consumer behavior and decision-making (Banister and Hogg, 2004; Grubb and Grathwohl, 1967).

\subsection{Congruency relationships between product/brand imagery and possible selves}

Central to the relationship between distastes and the undesired self is the notion of product-user imagery in self- 
congruity theory (Sirgy, 1982). Self-esteem plays a crucial role as a motivational factor here. Advertisers and marketing professionals use congruency with product-user imagery to position brands (Sirgy et al., 1997), creating typical consumers for their products through the use of role models in advertising. Different identities - and therefore positive and negative stereotypes - are salient at different times, thus affecting individuals' behavior in certain situations (Shih et al., 1999). Conformity to group norms largely depends upon the relevant social identity that is salient at the time (Reicher and Hopkins, 1996). The maintenance, enhancement and protection of selfesteem (within the context of the self-concept) links to both approach and avoidance behaviors in consumer research (Sirgy, 1982), and thus to anti-consumption-as-rejection. Anti-choice involves emotions which means that symbolic rather than functional attributes often prevail as reasons for rejecting products and services. Anti-choice therefore links to the protection of self-esteem, which connects, in turn, to negative aspects of the self, including the undesired self.

\section{An expanded integrative conceptualization of symbolic consumption}

The key original contribution of the expanded conceptualization (Fig. 1) is firstly, the integration of both consumption and anti-consumption in the modeling of symbolic consumption; and secondly the ability to capture different levels of inter- relationships within symbolic consumption (e.g. super-ordinate, middle and subordinate (including macro and micro), see Table 1). This new integrated conceptualization provides the basis for future research inter alia on anti-consumption.

The new expanded conceptualization (Fig. 1) builds on frameworks from earlier research by integrating Ligas and Cotte's (1999, p. 611) modeling of the brand negotiation process as an interaction between three environments (marketing, social and individual) into Banister and Hogg's (2004) congruency framework. In their original framework, "Congruency relationships between symbolic product/retail imagery and possible selves," Banister and Hogg (2004, p. 856) extend earlier theory-building about the interrelationships between self, product and audience (Grubb and Grathwohl, 1967). This expanded framework incorporates the range of different possible selves, and their associated audiences, which link to positive and negative symbolic meanings of consumption. The associated audiences include avoidance or out-groups, which are often seen in stereotypical ways (Englis and Solomon, 1995), generating "oppositional brand loyalty" (Muniz and O'Guinn, 2001, p. 420) and functioning as threats. The framework also elaborates the self-concept to include possible selves, thereby capturing the undesired self (Ogilvie, 1987) and the multi-dimensional nature of the self (Kleine et al., 1993). Protection and enhancement of the sense of self, and the avoidance of self-abasement (Sirgy, 1982), are important motivational drivers in this framework. Ligas and Cotte

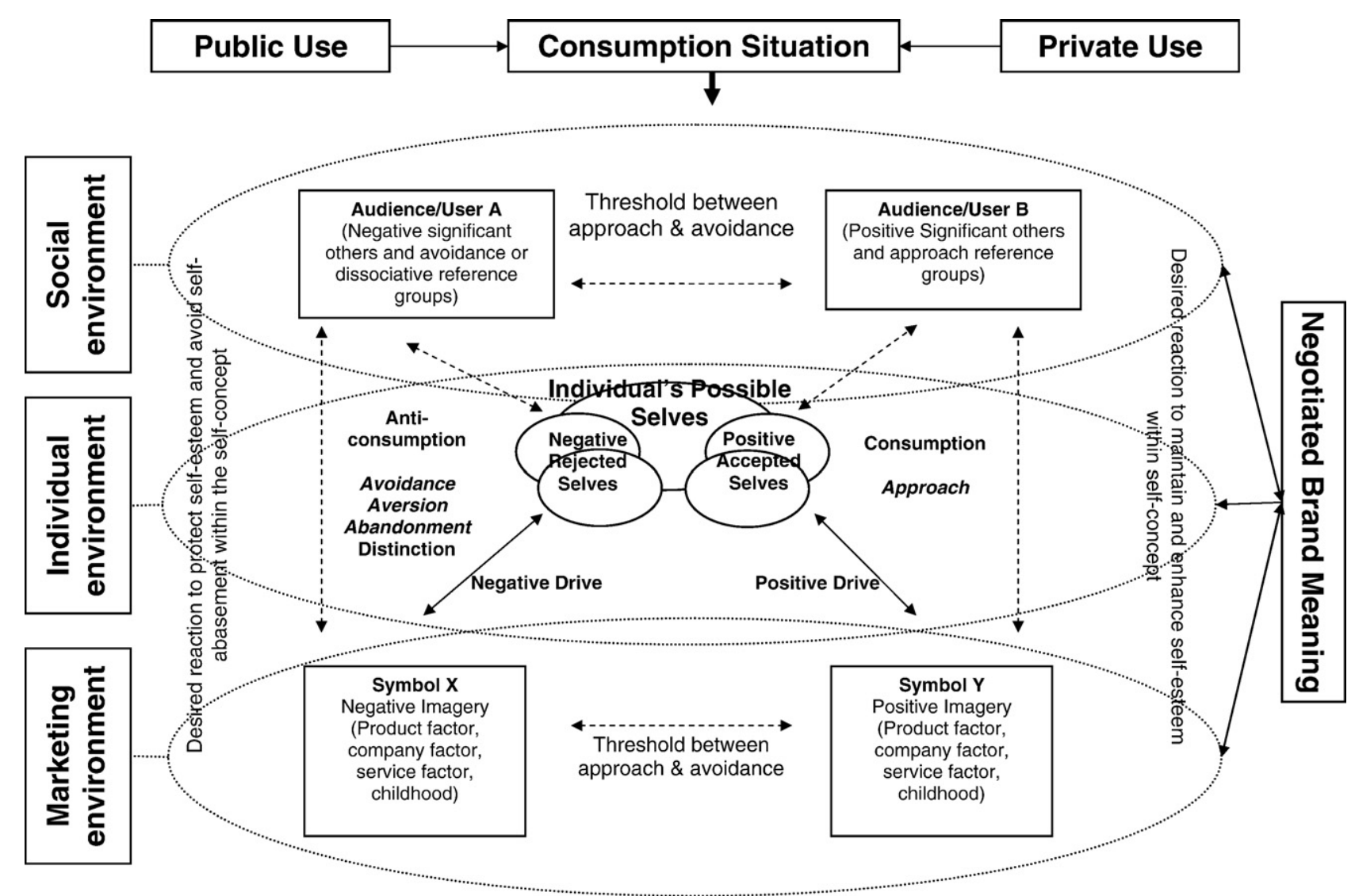

Fig. 1. Mapping symbolic (anti-) consumption: an expanded integrative conceptualization. 
Table 1

Research directions in (anti-) consumption

\begin{tabular}{|c|c|c|c|c|c|}
\hline Level $^{\mathrm{a}}$ & Label & Inter-relationship(s) & $\begin{array}{l}\text { Dominant } \\
\text { research focus } \\
\text { in relation to } \\
\text { consumption }\end{array}$ & $\begin{array}{l}\text { Research topics } \\
\text { include }\end{array}$ & Links to wider research issues/debates \\
\hline $\begin{array}{l}\text { Super- } \\
\text { ordinate }\end{array}$ & $\begin{array}{l}\text { Symbolic } \\
\text { consumption }\end{array}$ & $\begin{array}{l}\text { Positive and negative poles } \\
\text { (attraction and repulsion) } \\
\text { i.e. both consumption and } \\
\text { anti-consumption }\end{array}$ & $\begin{array}{l}\text { Reciprocal and } \\
\text { reflexive } \\
\text { dynamic(s) }\end{array}$ & $\begin{array}{l}\text { Approach-avoidance } \\
\text { thresholds }\end{array}$ & $\begin{array}{l}\text { Consumer ambivalence (Olsen, Wilcox, } \\
\text { and Olsson, 2005; Otnes et al., 1997; } \\
\text { Priester and Petty, 1996; Ruth, Brunel, } \\
\text { and Otnes, 2002) }\end{array}$ \\
\hline \multirow[t]{2}{*}{ Middle } & Consumption & $\begin{array}{l}\text { Positive axis around which } \\
\text { consumers, groups } \\
\text { and products revolve }\end{array}$ & $\begin{array}{l}\text { Three-way } \\
\text { interactions } \\
\text { across } \\
\text { individuals } \\
\text { groups and } \\
\text { products }\end{array}$ & $\begin{array}{l}\text { Positive symbolic } \\
\text { consumption }\end{array}$ & $\begin{array}{l}\text { Meanings of possessions Belk (1988); } \\
\text { Tian and Belk, 2005) } \\
\text { Congruency (Sirgy et al., 1997; } \\
\text { Kressmann et al., 2006) } \\
\text { Possession attachment } \\
\text { (Kleine, Kleine, and Allen, 1995) }\end{array}$ \\
\hline & $\begin{array}{l}\text { Anti-consumption } \\
\text { [as rejection] }\end{array}$ & $\begin{array}{l}\text { Negative axis around } \\
\text { which consumers, } \\
\text { groups and products } \\
\text { revolve }\end{array}$ & & $\begin{array}{l}\text { Negative symbolic } \\
\text { consumption }\end{array}$ & $\begin{array}{l}\text { Symbolic interactionism Ligas and } \\
\text { Cotte (1999) Solomon, 1983) } \\
\text { Brand communities } \\
\text { (Muniz and O’Guinn, 2001) }\end{array}$ \\
\hline $\begin{array}{l}\text { Subordinate } \\
\text { (Macro) }\end{array}$ & $\begin{array}{l}\text { Complex } \\
\text { components } \\
\text { of (anti-) } \\
\text { consumption }\end{array}$ & $\begin{array}{l}\text { Some combination } \\
\text { of consumers, } \\
\text { groups/audiences } \\
\& \text { products }\end{array}$ & $\begin{array}{l}\text { Molar: dyadic } \\
\text { relationships }\end{array}$ & $\begin{array}{l}\text { Interactions between } \\
\text { Product/consumer } \\
\text { Consumer/group } \\
\text { Product/group }\end{array}$ & $\begin{array}{l}\text { Decision-making; Identity } \\
\text { projects Kleine and Kleine (2000) } \\
\text { Imagery/advertising (Mick and Buhl, 1992) } \\
\text { Group processes (Bearden and Etzel, 1982; } \\
\text { Childers and Rao, 1992; Escalas, 2004; } \\
\text { Escalas and Bettman, 2003; Escalas and } \\
\text { Bettman, 2005; John, 1999; Moore and } \\
\text { Lutz, 1988; White and Dahl, 2006) }\end{array}$ \\
\hline \multirow[t]{4}{*}{$\begin{array}{l}\text { Subordinate } \\
\text { (Micro) }\end{array}$} & $\begin{array}{l}\text { Individual } \\
\text { components in } \\
\text { (anti-) consumption }\end{array}$ & $\begin{array}{l}\text { Consumers } \\
\text { [possible selves] }\end{array}$ & $\begin{array}{l}\text { Molecular: } \\
\text { Single element }\end{array}$ & $\begin{array}{l}\text { Self-esteem } \\
\text { (enhancement, } \\
\text { maintenance or } \\
\text { protection) } \\
\text { Self-discrepancy }\end{array}$ & $\begin{array}{l}\text { Motivation Sobh et al. (2006) personality; } \\
\text { emotions; self (Buchanan-Oliver, 2006; } \\
\text { Markus and Nurius, 1986; Ogilvie, 1987; } \\
\text { Schouten, 1991) } \\
\text { Self-concept Sirgy (1982); identity } \\
\text { self-discrepancy theory Sobh et al. (2006) } \\
\text { Social comparison } \\
\text { (Richins, 1991; Wood, 1989) }\end{array}$ \\
\hline & & Groups/audience & & Reference groups & $\begin{array}{l}\text { Categorization stereotyping group } \\
\text { membership Mangleburg et al. (2004) } \\
\text { Social identity }\end{array}$ \\
\hline & & Products & & $\begin{array}{l}\text { User stereotypes } \\
\text { Involvement } \\
\text { Imagery }\end{array}$ & Marketing communications \\
\hline & & & & & $\begin{array}{l}\text { Acquisition and disposition } \\
\text { (Curasi et al., 2004; } \\
\text { Price et al., 2000; Lastovicka and } \\
\text { Fernandez, 2005) }\end{array}$ \\
\hline
\end{tabular}

Mapping of levels, inter-relationships and research foci within symbolic consumption to wider debates.

a Categorization levels derived from Cantor and Mischel, (1979, p. 16).

(1999, p. 611), in their "Framework for the Brand Negotiation Process," emphasize the importance of the relationship between the consumer and his/her social context, and of the symbolic interactionist approach as a sound theoretical basis for future research. They map how consumers socially negotiate and adopt symbolic meanings; and how the consumer's self-concept alters as a result of social interaction. The new expanded framework adopts this dynamic approach to the marketing environment and the negotiation of brand meaning while superimposing the multiple-self perspective.

\subsection{The three environments: marketing, social and individual}

Producers strive to manage the marketing environment, using advertising and other media for the promotion of corporate imagery. However, managerially-driven messages often compete with other sources of information, such as marketplace beliefs and word of mouth, which are not always under marketer control, but which imbue brands with meaning (Ligas and Cotte 1999, p. 611). Marketplace beliefs can play a crucial role when consumers express strong feelings, both in terms of what they say and what they do (cf. Wilk's earlier studies, 1994, 1995, 1997, on distastes). Anti-consumption therefore becomes explicitly articulated as the rejection of products, brands and services.

The social environment involves symbolic interaction linked to public versus private consumption contexts, and encompasses the role of the audience (self reflexivity), most notably reference groups and intergenerational influences. Symbolic interactionism highlights the need to forge an 
understanding of the role of group-self co-ordinates in the negotiation and interpretation of brand meanings in the social environment (Ligas and Cotte, 1999, p. 612). Intergenerational influences (Moore et al., 2002) play a significant role in the process of consumer socialization (Ekstrom, 2006) with parents influencing children's consumption choices and brands. Socialization agents (parents, peers and the media) are all-important in the formation of values, emotions and attitudes and can stimulate both approach and avoidance behaviors, leading to the acceptance or rejection of products or services.

The individual environment includes childhood memories as well as the activation or implication of the self via interpretive discourses. Childhood memories can be an important stimulus to negation and rejection. Research on the formation of distastes (Banister and Booth, 2004; Wilk, 1997) and children's changing understanding of the congruency of self/brand imagery (Belk et al., 1982, 1984; Chaplin and John, 2005) reinforces this view of the important role of childhood memories. Childhood influences can function positively, serving as cues for the positive possible self (individual activation, Ligas and Cotte, 1999) and encouraging approach behavior, but can also operate negatively, where consumers absorb the negative associations that parents have about particular brands of products or services. Childhood memories can stimulate dislike and encourage aversion leading to such rejection behaviors as avoidance or abandonment. In addition consumers often seek to break ties with former now-rejected selves and reject the associated symbols, suggesting notions of abandonment (Hogg, 1998). Here symbolism aligns with the disposition of an old identity and the reconstruction of a new one, within the context of the identity project lifecycle (Kleine and Kleine, 2000).

\subsection{Negotiated brand meanings}

Ligas and Cotte (1999) identify three key components central to the negotiation of brand meaning: personality, physical attributes and functional characteristics. User-imagery stereotypes (Sirgy et al., 1997) represent a central component of brand personality providing consumers with immediate and obvious ways in which to compare and convey the images that different brands hold for them (Banister and Hogg, 2004). Stereotypical user imagery can be very rich in symbolic meanings (Sirgy et al., 1997) illustrating the importance of the iterative process between marketers and consumers in the circulation of meanings, often directly via advertising, which promotes images of typical users. Consumers tend to identify with brands which evoke consumer stereotypes congruent with their positive accepted self (Sirgy et al., 1997), and avoid and distinguish/distance themselves from brands with user stereotypes which they associate with their negative undesired self (Banister and Hogg, 2004; Ogilvie, 1987; Sirgy et al., 1997), leading to disidentification from avoidance (Lee et al., 2009-this issue; see also Elsbach and Bhattacharya, 2001) or dissociative groups (White and Dahl, 2006).

\subsection{Mapping anti-consumption within symbolic consumption}

The new framework maps congruency relationships between possible selves, product imagery and the three environments in relation to (anti)-consumption, demonstrating how social and individual environments are central to the creation and circulation of brand meanings in the marketplace. The framework illustrates the reciprocal nature of the relationships between consumption and anti-consumption for the first time, showing how the relationship between distastes (Bourdieu, 1984) and the undesired self (Ogilvie, 1987) provides the navigational cues and co-ordinates for the real (Ogilvie, 1987) or possible selves (Markus and Nurius, 1986). The new framework also seeks to demonstrate for the first time, the reflexive and reflective nature of the inter-relationship between consumption and anti-consumption within symbolic consumption, which has not been conceptualized before within the wider environmental contexts.

The new framework also captures the dynamic interaction between macro (e.g. environment) and micro (e.g. individual) level features. Consumer concerns, for instance, about the ethical sourcing of goods, the environment and the impact of globalization illustrate the tensions generated by the dialectic between the macro and the micro. These discourses often relate to other aspects of anti-consumption such as consumer empowerment (Shaw and Brailsford, 2006), downshifting and voluntary simplicity (Schor, 1998). However discursive formation of the self in relation to the wider environmental and global contexts (Fig. 1) confirms the blurring of the individual and social environments identified in earlier discussions (Ligas and Cotte, 1999, p. 611) and also how avoidance can encompass ideological and moral issues (Lee et al., 2009-this issue). Individual reasons for certain types of consumption can have wider social implications, which can result in potential conflicts between particular aspects of the self. For example a consumer's environmentally responsible self might consume organic foods on the grounds that these interfere less with the biological balance in the environment, yet other aspects of this environmentally responsible self might encourage the consumption of local foods (in order to counteract detriment to the environment on the basis of air miles), which might not always be organic. In this case the potential conflict could be between organic air miles or local GM [genetically modified] food, either of which might not be wholly acceptable to the socially informed environmentally responsible self. In addition, this same consumer could experience conflicts between individually informed and socially informed aspects of the self. For example their healthy self might encourage the view that organic is best, but again their environmentally responsible self might emphasize the environmental footprint associated with their choices. In this case individual reasons for consumption are in conflict with social reasons. The conundrum for socially and ecologically responsible consumers lies within the context of anticonsumption; and echoes aspects of negatively emotion-laden consumer decisions (Luce, 1998); as well as reflecting the ideological and moral issues within anti-consumption (Lee et al., 2009-this issue). 


\section{Mapping symbolic (anti-) consumption: illustrations from the conceptualization}

The expanded conceptualization (Fig. 1) offers a significant and original contribution to the small but developing field of anti-consumption research, bringing together a range of theoretical advances from disparate areas of study; and also refining understanding of the key motivational drivers of anticonsumption.

Worked examples of two particular sets of inter-relationships illustrate its potential generative power to specifically theorize and investigate anti-consumption: firstly, the interaction between avoidance, aversion and abandonment as key attitudinal components in the articulation of anti-consumption; and secondly, the inter-relationship between distastes and the undesired self as mediated by the marketing, social and individual environments. These aspects of anti-consumption provide important navigational cues and co-ordinates for the real self (or possible selves), illustrating the reciprocal relationships between the positive (consumption) and the negative (anti-consumption-as-rejection) within symbolic consumption (Fig. 1).

\subsection{Avoidance, aversion and abandonment in the articulation of anti-consumption}

The expanded conceptualization (Fig. 1) depicts the articulation of anti-consumption via aversion, avoidance and abandonment, which involve different degrees of anti-choice or anti-consumption (Hogg, 1998). The distinctions between aversion, avoidance and abandonment link to the strength of feelings and behaviors they express (despite earlier research suggesting elements of overlap, Hogg, 1998). Aversion links strongly to the affective aspects of attitudes, whereas avoidance and abandonment have stronger connections to the behavioral elements of attitudes. Aversion (expressed as dislike, disgust, revulsion) seems to stimulate behavioral responses of either avoidance or abandonment. Aversion therefore tends to precede or appear in conjunction with consumers' expressions of avoidance or abandonment. Aversion involves the psychological or physical action of turning away from something. Avoidance involves the act of staying away from or moving away from something. Abandonment involves the action of giving up something previously consumed. Abandonment embodies the connotation that a deliberate choice has been made.

The important and complex inter-relationship among expressions of aversion, avoidance and abandonment is evident in the articulation of anti-consumption. Aversion combined with avoidance is seen in consumers' determination to distance themselves from negative stereotypical images, and to cleave to the preferred images of chosen social groups which are more congruent with their self-images, illustrating the importance of salience in the accentuation of in-groups and out-groups (Hogg and Abrams, 1998). Sometimes strong feelings such as disgust and revulsion result in aversion linked to avoidance. In the context of describing the properties of food, Wilk (1997) identifies the importance of odor and texture in distastes, while Rozin and Fallon (1987) describe elements of visceral disgust. Similarly aversion and avoidance sometimes link to the abandonment of earlier self-images (e.g. ex-smokers who come to dislike the smell of cigarette smoke and start to avoid smoky atmospheres) reflecting Kleine and Kleine's (2000) point about how individuals manage different aspects of their self-concept by discarding certain facets of their identity as their self-concept evolves.

\subsection{The relationship between distastes, the undesired self and negative brand meanings}

The extended integrated framework (Fig. 1) also suggests how the dialectic relationship between consumption and anticonsumption might provide cues and co-ordinates for different possible selves within symbolic consumption. The framework captures the inter-relationships between product imagery and different possible selves, as mediated by the three environments (marketing, social and individual).

The concern with negation, and particularly rejection, in this article leads to a concentration on anti-consumption, and the specific focus here is on the inter-relationship between distastes and the undesired self as embedded in the integrated framework. Distastes, or the refusal of tastes (Bourdieu, 1984), represent the navigational cues for the undesired self(Ogilvie, 1987; Banister and Hogg, 2004); and their relationship to avoidance or dissociative (White and Dahl, 2006) groups represent the coordinates (Simmel, 1955) for the undesired self. The expanded conceptualization maps the relationship between distastes (Bourdieu, 1984) and the undesired self (Ogilvie, 1987) and reflects the reciprocal dialectic between tastes/distastes and possible selves.

Different elements of the marketing, social and individual environments generate the navigational cues for the undesired self and combine with the user-imagery stereotypes, physical attributes and functional characteristics. In interpreting brand imagery, consumers draw on a range of sources including marketing-sponsored meanings (e.g. corporate communications and advertising); product features (e.g. ability to meet expectations in terms of functional characteristics or physical attributes) (Dalli et al., 2005); as well as on intergenerational influences, childhood memories and service aspects. In terms of distastes, the role of user stereotypes potentially dominates the negotiation of brand meanings in generating negative imagery. Accentuation (Hogg and Abrams, 1998) and social comparison (Hogg and Abrams, 1998) are important for identifying the cues for distastes and thus the group co-ordinates for the undesired self. Physical experiences of distastes involve smell and texture which can provoke some of the strongest expressions of negative feelings, reflecting disgust and revulsion and childhood memories and sometimes providing important "triggers for physical revulsion" (Wilk, 1997, p. 187). Negative brand and product meanings (and thus distastes) generate expressions of aversion leading to avoidance or abandonment.

Marketing campaigns promote product-user stereotypes, personalized by consumers to represent images of positive 
and negative possible selves (Cross and Markus, 1991). These function as navigational cues, providing the basis for consumers to identify their in-groups and out-groups; and also represent the co-ordinates for the undesired self (Markus and Nurius, 1986; Ogilvie, 1987). Consumers therefore regularly use stereotypes to distinguish between product and service brands, tending to identify with stereotypes congruent with their positive accepted self (Sirgy et al., 1997) and avoiding/distinguishing/ distancing themselves from those they associate with negative user stereotypes and their undesired self (Ogilvie, 1987; Sirgy et al., 1997).

Through disidentification from avoidance (Elsbach and Bhattacharya, 2001; Lee et al., 2009-this issue) or dissociative groups (White and Dahl, 2006), fellow consumers represent important sources of negative imagery and brand meanings, and represent the social group co-ordinates for undesired selves. However, Lee et al. (2009-this issue) suggest a potentially important distinction in the different roles played by the undesired self and avoidance groups in understanding anti-consumption and brand avoidance. The undesired self seems to offer a more accurate set of cues for the real self or possible selves, while avoidance groups offer less accurate and more stereotypical coordinates for aspects of the self.

Finally, two other important distinctions that remain underexplored are, firstly, the distinction between group identities "that are based on common bonds (attachment to other group members) and those based on common identity (collective identities)" (Prentice et al., 1994 in Brewer and Gardner, 1996, p. 83) as these potentially represent important sources of different co-ordinates for the self in consumption settings, and secondly, the distinction between selection and influence, for example, "a smoker may tend to have smoking friends, because once somebody is a smoker, he or she is likely to meet other smokers... and thus has more opportunities to form friendships with them (selection). At the same time it may have been friendship with a smoker that made him or her start smoking in the first place (influence)" (Steglich et al., 2004, p. 2). This distinction between influence and selection mechanisms could inform understanding of how group dynamics work for approach/associative and avoidance/dissociative groups.

\section{Research directions: anti-consumption within symbolic consumption}

The expanded conceptualization (Fig. 1) offers different levels - super-ordinate, middle, and subordinate (macro and micro) (Cantor and Mischel, 1979)-for investigation and theory-building. Table 1 outlines the directions for future research, which flow from these levels, in relation to the wider debates within consumer behavior research (Table 1: column 5).

These research directions link to other areas of theory that consumer behavior researchers traditionally draw on extensively (e.g. foundational disciplines such as social psychology, psychology and sociology) and indicate possible contributions at the conceptual, methodological, empirical and substantive levels, as well as implications for theory, research, methods and practice.

\subsection{Super-ordinate level: the positive and negative poles within symbolic consumption}

The super-ordinate level (Fig. 1 and Table 1) integrates the reciprocal and reflexive inter-relationships, showing how symbolic consumption revolves around positive and negative poles in a dynamic relationship of attraction and repulsion. Bourdieu (1984) and Ogilvie (1987) identify the dynamic dialectic between positive and negative in their respective spheres of sociology/social anthropology (tastes/distastes) and social psychology (undesired versus desired self). This expanded framework combines their contributions, along with explicit recognition of the role of the audience, or social reference group, to depict the investment of products with meanings by individuals. Very little extant research focuses on the reciprocity of the relationship between positive and negative poles.

This new conceptualization suggests that approach-avoidance thresholds might provide ways of understanding how this series of reflexive relationships work. Considerable work in psychology identifies how approach and avoidance motivations instigate behavior (Elliot and Thrash, 2002, p. 804). Early work in retail contexts (Donovan and Rossiter, 1982; Donovan et al., 1994) examines the impact of multiple influences on approach-avoidance conflicts and later work (Hogg and Penz, 2007, 2008) seeks to understand how approachavoidance might fit into consumer ambivalence. Consumer ambivalence involves "mixed emotions" (Otnes et al., 1997, p. 80). The positive and negatives poles of symbolic consumption (Fig. 1) might capture how ambivalence incorporates "the simultaneous existence of attraction and repulsion" (Smelser, 1998, p. 5). Earlier research on ambivalence suggests attitudes embrace separate positive and negative aspects and should not therefore be conceptualized along a bipolar continuum (Priester and Petty, 1996). Research into consumer ambivalence to incorporate this more nuanced understanding of how approach-avoidance works is still in the very early stages, but could significantly explain some of the dynamic interactions conceptualized in Fig. 1. In addition earlier work on attitudes and ambivalence assumes a global view of attitudes and ambivalence (Armitage and Connor, 2000) whereas Chaiken et al. (1995) conceptualize "three forms of evaluative inconsistency: cognitive-affective; affective-evaluative, and evaluative-cognitive" (Armitage and Connor, 2000, p. 1430). These different forms of evaluative inconsistency could also influence the assumptions traditionally brought to examining congruency within symbolic consumption, which use a global approach to attitudes, rather than trying to elicit different evaluative aspects of attitudes by linking these three types of evaluative inconsistency to congruency.

\subsection{Middle level: the positive and negative axes of symbolic consumption}

The middle level (Fig. 1 and Table 1) conceptualizes the inter-relationships of consumers, products and audiences, which Grubb and Grathwohl (1967) originally model around 
a positive axis. Banister and Hogg (2004) include a negative axis in their initial revision of Grubb and Grathwohl's framework. The inter-relationships around these positive and negative axes are at the heart of the expanded conceptualization (Fig. 1), and represent some of the extensive work that has already been done into the positive aspects of symbolic consumption. Sirgy et al. (1997), for instance, provide an important examination of product/consumer imagery within the context of user stereotypes in order to establish the source of socially-derived meanings of products or brands. By comparison there is relative neglect of negative aspects (e.g. anti-consumption) in previous research, apart from some important seminal work in social anthropology (Wilk, 1994, $1995,1997)$ and some exploratory consumer behavior studies (e.g. Banister, 2001; Banister and Hogg, 2004; Hogg, 1998; Lee et al., 2009-this issue; Sobh et al., 2006).

The middle level of symbolic consumption encompasses a range of dynamic processes. The revolution of product, consumer and social group around the negative axis (Fig. 1) represent negation and rejection and their links to anti-consumption. Studies of this negative axis via distastes and the undesired self could move beyond the traditional categories of image-laden products (Banister and Hogg, 2004; Birdwell, 1968; Grubb and Grathwohl, 1967) and services (Schouten, 1991) to more mundane categories. Researchers traditionally view grocery shopping as mundane (Kleine et al., 1993) or ordinary (Gronow, 2001) but grocery shopping represents a potentially rich research site. Food in particular emerges as an important vehicle for the expression of distastes in earlier studies (Wilk, 1994, 1995, 1997) and inherently involves both functional and symbolic aspects (Goffman, 1959), linking to both emotional and behavioral aspects of consumer behavior. For example, an examination of a product category/retail channel (grocery retailing), which is increasingly becoming an important context for self-expression, could elicit the interdependence between functional and expressive aspects of consumers' social identities. Ethnographic studies could examine consumers' lived experiences of user-imagery stereotypes during their shopping trips, as well as the physical and functional characteristics of products and retail outlets, which drive consumers' feelings, emotions and behaviors. This examination of consumers' experiences of grocery shopping might provide an interesting contrast to positive aspects of symbolic consumption with different weightings of crucial influences on perceptions of product imagery (e.g. word of mouth or reference group influences).

\subsection{Subordinate level: macro/molar and micro/molecular perspectives on symbolic consumption}

The subordinate levels (Fig. 1 and Table 1) can be split into macro/molar or micro/molecular, although this split is potentially a "fuzzy categorization" (Cantor and Mischel, 1979, p. 8ff) because the interactions between consumer, product and the social group are central to all manifestations of symbolic consumption. However for ease of discussion, while recognizing the risks of oversimplification, the subordinate category divides into two sub-levels.

\subsubsection{The subordinate: macro/molar level}

The subordinate/macro level tends to concern itself with researching molar/dyadic relationships (i.e. consumer/social group; consumer/product; social group/product). Sirgy's classic paper (1982) reviews a series of studies, which use congruence to examine self/product imagery relationship, yet researchers rarely explicitly address the social context in these studies. Kressmann et al. (2006) more recently connect the direct and indirect effects of self-image congruence to wider marketing concerns, such as brand loyalty. They identify significant managerial implications, which link firstly to developing clear brand personalities; secondly to enhancing brand relationship quality; and thirdly to specifically targeting highly involved customers (Kressmann et al., 2006, p. 962).

Fournier's (1998b) work on self-brand relationships represents a significant extension in understanding this important interaction; Escalas (2004) and Chaplin and John (2005) further extend this work on self-brand relationships. Future research methods could include the collection of narratives and stories to elicit childhood memories to support earlier views of the role of life histories in consumer experiences (Mick and Buhl, 1992; Thompson, 1996), illustrating how an individual's understanding of self-brand meanings flows from a dialogue among "personal goals, life history, context-specific interests, and the multitude of countervailing cultural meanings" (Thompson and Haytko, 1997, p. 16). Consumers' narratives and stories could provide a means by which to trace the process of consumer socialization (John, 1999), incorporating the formation of both tastes and distastes alongside negative and positive aspects of identity.

A recent study links self-discrepancy theory to feared selves and emotions to provide clues about the potential role of "agitation- and dejection-related affects [within symbolic consumption]" (Carver et al., 1999, p. 783). These authors argue that "an avoidance motive (feared self) dominates anxiety and guilt if the feared element is nearby but ... an associated approach motive (ought self) dominates anxiety and guilt if the feared element is more remote" (Carver et al., 1999, p. 783), thus suggesting the potential to explore the approach-avoidance thresholds in the expanded conceptualization. The relationship between self-discrepancy theory, feared selves and emotions might translate into explaining, in part, the reflexive nature of different possible selves (feared versus ought self) and approach/avoidance motivation. Other recent work identifies the role of the undesired self within the context of selfdiscrepancy theory (Heppen and Ogilvie, 2003), which also potentially might offer some valuable additional insights into the role of emotions and discrepancy reduction. "While both ideal and feared discrepancies were correlated with dejectionrelated emotions (i.e. depression and its conceptual opposite, happiness), feared discrepancy was the stronger predictor [of dejection-related emotions compared with] agitation-related emotions anxiety, guilt and their conceptual opposite, contentment" (Heppen and Ogilvie, 2003 p. 349). Within the context of consumer behavior, Sobh et al. (2006) seek to clarify the interaction between motivation and emotions, drawing on self-discrepancy theory and emotions within the context of 
(anti-) consumption. "Undesired self-discrepancy" (Heppen and Ogilvie, 2003, p, 366) could be an important explanatory variable of the main relationships around the negative axis in the expanded conceptualization (Fig. 1), and could link to other "moderators of self-discrepancy relationships with emotions" (Heppen and Ogilvie, 2003, p. 366). These moderators include situational variables, levels of product involvement and selfmonitoring, especially as earlier research points to the moderating effect of self-monitoring on "the relationship between self-discrepancies and affective states" (Gonnerman et al., 2000, p. 810).

\subsubsection{The subordinate: micro/molecular level}

Research at the subordinate/micro level tends to concentrate primarily on just one molecular component (i.e. consumer or product or audience), often within the overall context of all three components. However the work on self-monitoring (e.g. Auty and Elliott, 1998a,b, 2001; Hogg et al., 2000) demonstrates that the suggested division at the subordinate level between molar and molecular is somewhat fuzzy. Studies of individual dispositions, such as self-monitoring, examine consumer behavior within the context of symbolic consumption and particularly product or brand meanings. Other research about the individual tends to concentrate on motivation and selfesteem. The linkages of approach and avoidance to valence elucidate the conflicts highlighted above at the super-ordinate level of symbolic consumption (Section 5.1).

The combination of personality theory with emotions promises a rich seam for investigating and theorizing (anti-) consumption. Firstly, consumers' appraisal both of themselves and others (Griner and Smith, 2000) could suggest how primary appraisal influences affective reactions (Larsen, 2000, p. 653) within symbolic consumption. Secondly, individuals' different ways of "responding to incentives and threats" (Larsen, 2000, p. 653) may explain consumers' differential reactions to the desired self/tastes and undesired self/distastes within symbolic consumption, lending support to Bourdieu's (1984) argument that consumers have more powerful and strongly held views of distastes than of tastes. Despite the relative neglect of emotions and personality traits within social psychology, individual differences could provide a useful way of examining emotions (Larsen, 2000, p. 651). Future research could promote understanding of symbolic consumption by drawing on developments in "neuroscience, social psychology, developmental psychology, and cognitive science...[and using] experiments and other forms of systematic observation... to ground and guide theory development" (Larsen, 2000, p. 652).

\section{Conclusion}

Rejection characterizes anti-consumption and resides in the interstices of consumption choices. A new expanded conceptualization maps the main negative and positive axes around which anti-consumption and consumption revolve. This integrative framework (Fig. 1) captures the reciprocal and reflexive relationships within symbolic consumption that encompass and harness both affirmation (and thus consump- tion-as-acceptance) and negation (and thus anti-consumptionas-rejection) representing poles of attraction and repulsion.

The new conceptualization identifies a series of interrelationships, and illustrations suggest how this expanded conceptualization can aid the theorizing and investigation of anticonsumption. In this context, anti-consumption illustrates the interaction between avoidance, aversion and abandonment in the articulation of anti-consumption, and the relationship between distastes and the undesired self. The marketing, social and individual environments influence tastes and distastes which, in turn, provide important navigational cues and coordinates for the real self (or possible selves) within symbolic consumption. Bourdieu (1984) and Ogilvie (1987), respectively, describe how distastes represent an important mirroring of tastes, and how the undesired self represents the co-ordinates for the real self. The new framework conceptualizes the dynamic relationship between the positive and negative poles and the associated reciprocal and reflexive relationships within symbolic consumption.

The theory-building that flows from the expanded conceptualization has some potential limitations. Culture provides a critical context for understanding the meanings that consumption generates. The positive and negative aspects of symbolic consumption could vary by cultural context, particularly because of potentially differing views of the self in relation to the social group across individualistic and collectivistic cultures. Research shows that different self-systems characterize individualistic and collectivistic societies (Markus and Kitayama, 1991) suggesting that notions of the self (particularly independent versus interdependent views of the self) may vary cross culturally. One example in the expanded conceptualization, above, is the modeling of consumer motivation within symbolic consumption in terms of the enhancement, maintenance and protection of self-esteem. Debates about the role of self-enhancement across cultures (Heine and Lehman, 1999; Markus and Kitayama, 1991) include the view that "lack of selfenhancement is intrinsic to the interdependent self" (Kurman, 2001, p. 1706). Similarly, self-discrepancy theory potentially works in different ways according to the cultural context (cf. Heine and Lehman's (1999) study of Japan, for instance). The inter-relationships conceptualized in Fig. 1 may therefore be idiographic rather than nomothetic; the cultural context impinges on understanding symbolic consumption, including different facets of anti-consumption.

Anti-consumption assumes a variety of forms. These forms range from resistance to rejection, and have varying degrees of visibility. Resistance, for instance, can take the form of active behaviors in the market place (e.g. boycotting, ethical consumption, voluntary simplicity) (Fournier, 1998a; Lee, 2006). Rejection, in contrast, involves products not purchased; services not accessed; and brands not chosen, which all represent rather more passive behaviors, and are therefore much more difficult for marketing managers to recognize and counteract.

The main factors that influence negative brand meanings in the market place are corporate imagery, user stereotypes (positive and/or negative), and product features (e.g. ability to 
meet expectations) (Dalli et al., 2005); along with service, intergenerational influences and childhood memories. Some of these are more amenable to management counter-strategies than others. Marketing management needs to develop a much more nuanced understanding of how rejection and negation translates into the avoidance of particular products by consumers. This more nuanced understanding could significantly inform the development of marketing communications strategies, particularly in social marketing and public policy campaigns.

\section{Acknowledgements}

We thank Susan Auty (Lancaster University Management School), Sarah Todd (University of Otago), the two reviewers and the three editors of this special issue for their invaluable comments on earlier drafts of this article. We acknowledge the funding from Agence Nationale de la Recherche (ANR-06BLAN-0079-01) for the University of Paris XII-led project: "NACRE: New approaches to Consumer Resistance [Resistance du consommateur: approaches multi-niveaux et crossculturelles d'un phenomene emergent]" which provides support for the first two authors' continuing work in this area.

\section{References}

Armitage CJ, Connor M. Attitudinal ambivalence: a test of three key hypotheses. Pers Soc Psychol Bull 2000;226(11):1421-32 November.

Auty S, Elliott R. Social identity and the meaning of fashion brands. In: Englis BG, Olofsson O, editors. European Advances in Consumer Research, vol. 3. Provo, UT: Association of Consumer Research; 1998a. p. 1-10.

Auty S, Elliott R. Fashion involvement, self-monitoring and the meaning of brands. J Prod Brand Manag 1998b;7(2):109-21.

Auty S, Elliott R. Being like or being liked: identity vs. approval in a social context. In: Gilly MC, Meyers-Levy J, editors. Advances in Consumer Research, vol. 28. Provo, UT: Association of Consumer Research; 2001. p. 235-41.

Banister EN, Hogg MK. Mapping the negative self: from 'so not me'... to 'just not me'. In: Gilly MC, Meyers-Levy J, editors. Advances in Consumer Research, vol. 28. Provo, UT: Association for Consumer Research; 2001. p. $242-7$.

Banister EN, Booth GJ. Tastes, distastes and disgusts: young consumers' positive and negative experiences of food. In: Kahn BE, Luce MF, editors. Advances in Consumer Research, vol. 31. Valdosta, Georgia: Association for Consumer Research; 2004. p. 106-11.

Banister EN, Hogg MK. Negative symbolic consumption and consumers' drive for self- esteem: the case of the fashion industry. Eur J Mark 2004;38(7):850-68.

Bearden WO, Etzel MJ. Reference group influence on product and brand purchase decisions. J Consum Res 1982;9:183-94.

Belk RW. Possessions and the extended self. J Consum Res 1988;15:139-68.

Belk RW, Bahn KD, Mayer RN. Developmental recognition of consumption symbolism. J Consum Res 1982;9:4-17.

Belk RW, Mayer R, Driscoll A. Children's recognition of consumption symbolism in children's products. J Consum Res 1984;10:386-97.

Biernat M, Vescio TK, Green ML. Selective self-stereotyping. J Pers Soc Psychol 1996;6(71):1194-209.

Birdwell AE. A study of the influence of image congruence on consumer choice. J Bus 1968;41:76-88 [Jan].

Bourdieu P. Distinction: A Social Critique of the Judgment of Taste translated by Richard Nice. London: Routledge and Kegan; 1984.

Brewer MB, Kramer RM. The psychology of inter-group attitudes and behavior Annu Rev Psychol 1985;36:219-43.
Brewer MB, Gardner W. Who is this "we"? Levels of collective identity and self representations. J Pers Soc Psychol 1996;71(1):83-93.

Buchanan-Oliver M. Framing the negative self: consumers and consumption. In: Pechman C, Price L, editors. Advances in Consumer Research, vol. 33. Duluth, MN: Association for Consumer Research; 2006. p. 350-1.

Cantor N, Mischel W. Prototypes in person perception. In: Berkowitz L, editor. Advances in Experimental Social Psychology, vol. 12. New York: Academic Press; 1979. p. 4-52.

Cantor N, Markus H, Niedenthal P, Nurius P. On motivation and the self concept. In: Sorrentino RM, Higgins ET, editors. Handbook of Motivation and Cognition: Foundations of Social Behaviour. Colchester: Wiley; 1986. Chapter 4.

Carver CS, Lawrence JW, Scheier MF. Self-discrepancies and affect: incorporating the role of feared selves. Pers Soc Psychol Bull 1999;25(7):783-92 July.

Chaiken S, Pomerantz EM, Giner-Sorolla R. Structural consistency and attitude strength. In: Petty RE, Krosnick JA, editors. Attitude strength: Antecedents and consequences. Mahwah, NJ: Lawrence Erlbaum; 1995. p. 387-412.

Chaplin LN, John DR. The development of self-brand connections in children and adolescents. J Consum Res 2005;32:119-29 [June].

Childers TL, Rao AR. The influence of familial and peer-based reference groups on consumer decisions. J Consum Res 1992;19:198-211.

Cross S, Markus H. Possible selves across the life span. Hum Dev 1991;34:230-55.

Curasi CF, Price LL, Arnould EJ. How individuals' cherished possessions become families' inalienable wealth. J Consum Res 2004;31(3):609-23.

Dalli D, Romani S, Gistri G. Brand dislike: evidence from qualitative research and scale development. Proceedings of the 34th EMAC conference. Milan; 2005.

Dittmar H. The Social Psychology of Material Possessions. Hemel Hempstead: Harvester Press; 1992.

Donovan RJ, Rossiter JR. Store atmosphere: an environmental psychology approach. J Retail 1982;58(1):34-57.

Donovan RJ, Rossiter JR, Marcoolyn G, Nesdale A. Store atmosphere and purchasing behavior. J Retail 1994;70(3):283-94.

Eisenstadt D, Leippe MR. The self-comparison and self-discrepant feedback: consequences of learning you are what you thought you were not. J Pers Soc Psychol 1994;67(4):611-26.

Ekstrom KM. Consumer socialization revisited. Research in Consumer Behavior, vol. 10. Elsevier; 2006. p. 71-98.

Elliot AJ, Thrash TM. Approach-avoidance motivation in personality: approach and avoidance temperaments and goals. J Pers Soc Psychol 2002;82(5):804-18.

Elsbach KD, Bhattacharya CB. Defining who you are by what you're not: organizational disidentification and the National Rifle Association. Organ Sci 2001;12(4):393-413.

Englis BG, Solomon M. To be and not to be: lifestyle imagery, reference groups, and the clustering of America. J Advert 1995;24(1):13-29.

Escalas J. Narrative processing: building consumer connections to brands. J Consum Psychol 2004;14(1\&2):168-79.

Escalas J, Bettman JR. You are what they eat: the influence of reference groups on consumers' connections to brands. J Consum Psychol 2003;13(3):339-48.

Escalas J, Bettman JR. Self construal, reference groups and brand meaning. J Consum Res 2005;32(3):378-90.

Fournier S. Special session summary. Consumer resistance: societal motivations, manifestations and implications in the consumer behavior domain. In: Alba JW, Hutchinson W, editors. Advances in Consumer Research, vol. 25. Provo, Utah: Association of Consumer Research; 1998a. p. 88-90.

Fournier S. Consumers and their brands: developing relationship theory in consumer research. J Consum Res 1998b;24:343-73 (March).

Goffman E. The Presentation of Self in Everyday Life. Garden City, NY: Doubleday-Anchor; 1959.

Gonnerman ME, Parker CP, Lavine H, Huff J. The relationship between selfdiscrepancies and affective states: the moderating roles of self-monitoring and standpoints on the self. Pers Soc Psychol Bull 2000;26(7):810-9 July.

Griner LA, Smith CA. Contributions of motivational orientation to appraisal and emotion. Pers Soc Psychol Bull 2000;26(6):727-40 June.

Gronow J. Ordinary consumption. New York: Routledge; 2001. 
Grubb EL, Grathwohl HL. Consumer self-concept, symbolism and market behavior: a theoretical approach. J Mark 1967;31:22-7.

Haslam SA, Oakes PJ, McGarthy C, Turner JC, Reynolds KJ, Eggins RA. Stereotyping and social influence: the mediation of stereotype applicability and sharedness by the views of in-group and out-group members. Br J Soc Psychol 1996;35:369-97.

Heine SJ, Lehman DR. Culture, self-discrepancies, and self-satisfaction. Pers Soc Psychol Bull 1999;25(8):915-25.

Heppen JB, Ogilvie DM. Predicting affect from global self-discrepancies: the dual role of the undesired self. J Soc Clin Psychol 2003;22(4): $347-68$.

Hilton JL, von Hippel W. Stereotypes. Annu Rev Psychol 1996;47:237-71.

Hogg MK. Anti-constellations: exploring the impact of negation on consumption. J Market Manag 1998;14:133-58.

Hogg MK, Penz E. Online and offline purchasing strategies: a preliminary investigation and conceptualization of approach-avoidance conflicts in shopping behavior. In: Lowrey T, editor. Bricks and Mortar Shopping in the 21st century. Mahwah, New Jersey: Lawrence Erlbaum Associates; 2008. p. 53-8. chapter 5 .

Hogg MK, Penz E. Integrating approach-avoidance conflicts into consumer ambivalence: comparing retail contexts. San Francisco: Society for Consumer Psychology; 2007 (Aug).

Hogg MA, Abrams D. Social Identifications: a social psychology of intergroup relations and group processes. London: Routledge; 1998.

Hogg MK, Cox AJ, Keeling KA. The impact of self-monitoring on image congruence and product/brand evaluation. Eur J Mark 2000;34(5/6):641-66.

John DR. Consumer socialization of children: a retrospective look at twenty-five years of research. J Consum Res 1999;26:183-213 (December).

Kleine RE, Kleine SS. Consumption and self-schema changes throughout the identity project life cycle. In: Hoch SJ, Meyer RJ, editors. Adv Consum Res, vol. 27. Provo UT: Association for Consumer Research; 2000. p. 279-84.

Kleine RE, Kleine SS, Kernan JB. Mundane consumption and the self: a socialidentity perspective. J Consum Psychol 1993;2(3):209-35.

Kleine SS, Kleine RE, Allen CT. How is a possession 'me' or 'not me'? Characterising types and an antecedent of material possession attachment. J Consum Res 1995;22(December):327-43.

Kressmann F, Sirgy MJ, Herrman A, Huber F, Huber S, Lee DJ. Direct and indirect effects of self-image congruence on brand loyalty. J Bus Res 2006;59:955-64.

Kurman J. Self-enhancement: is it restricted to individualistic cultures? Pers Soc Psychol Bull 2001;27(12):1705-16 December.

Larsen RJ. Emotion and personality: introduction to the special symposium. Pers Soc Psychol Bull 2000;26(6):651-4 June.

Lastovicka JL, Fernandez KV. Three paths to disposition: the movement of meaningful possessions to strangers. J Consum Res 2005;31(4):813-24.

Lee MSW. Anti-consumption Research: Exploring the Boundaries of Consumption. In: Gregory G, Davis T, Craig-Lees M, editors. Asia-Pacific Advances in Consumer Research. Duluth MN: Association for Consumer Research; 2006. p. 73-4.

Lee MSW, Motion J, Conroy D. Anti-consumption and brand avoidance. Journal of Business Research 2009;62:169-80 (this issue); [Special Issue on Anti consumption]. doi:10.1016/j.jbusres.2008.01.024.

Ligas M, Cotte J. The process of negotiating brand meaning: a symbolic interactionist perspective. In: Arnould EJ, Scott LH, editors. Advances in Consumer Research, vol. 26. Provo UT: Association for Consumer Research; 1999. p. 609-14.

Luce MF. Choosing to avoid: coping with negatively emotion-laden consumer decisions. J Consum Res 1998;24:409-33 (March).

Mangleburg TF, Doney PM, Bristol T. Shopping with friends and teens' susceptibility to peer influence. J Retail 2004;80:101-16.

Markus H, Kitayama S. Culture and the self: implications for cognition, emotion and motivation. Psychol Rev 1991;98:224-53.

Markus H, Nurius P. Possible selves. Am Psychol 1986;41(9):954-69.

Mead GH. Mind, Self and Society. Chicago: University of Chicago Press; 1934.

Mick DG, Buhl C. A meaning-based model of advertising experiences. J Consum Res 1992;19(3):317-39.

Moore ES, Lutz RJ. Intergenerational influences in the formation of consumer attitudes and beliefs about the marketplace: mothers and daughters. In:
Houston MJ, editor. Advances in Consumer Research, vol. 15. Provo UT: Association for Consumer Research; 1988. p. 461-7.

Moore ES, Wilkie WL, Lutz RJ. Passing the torch: intergenerational influence as a source of brand equity. J Mark 2002;66:17-37 (April).

Muniz AM, O'Guinn TC. Brand community. J Consum Res 2001;27(4):412-32.

Ogilvie DM. The undesired self: a neglected variable in personality research. J Pers Soc Psychol 1987;52(2):379-85.

Otnes C, Lowrey TM, Shrum LJ. Toward an understanding of consumer ambivalence. J Consum Res 1997;24(1):80-93.

Olsen SO, Wilcox J, Olsson U. Consequences of ambivalence on satisfaction and loyalty. Psychol Mark 2005;22(3):247-69.

Prentice D, Miller D, Lightdale J. Asymmetries in attachments to groups and to their members: distinguishing between common-identity and common-bond groups. Pers Soc Psychol Bull 1994;20:484-93.

Price LL, Arnould EJ, Curasi CF. Older consumers' disposition of special possessions. J Consum Res 2000;27(2):179-202.

Priester JR, Petty RE. The gradual threshold model of ambivalence: relating the positive and negative bases of attitudes to subjective ambivalence. J Pers Soc Psychol 1996;71(3):431-49.

Reicher S, Hopkins N. Seeking influence through characterizing self-categories: an analysis of anti-abortionist rhetoric. Br J Soc Psychol 1996;35:297-311.

Richins ML. Social comparison and the idealized images of advertising. J Consum Res 1991;18(1):71-84.

Rozin P, Fallon A. A perspective on disgust. Psychol Rev 1987;94(1):23-41.

Ruth JA, Brunel FF, Otnes CC. Linking thoughts to feelings: investigating cognitive appraisals and consumption emotions in a mixed-emotions context. J Acad Mark Sci 2002;30(1):44-58.

Schor JB. Downshifters: architects of a new American dream. In: Alba JW, Hutchinson W, editors. Advances in Consumer Research, vol. 25. Provo, Utah: Association of Consumer Research; 1998. p. 88-9.

Schouten JW. Selves in transition: symbolic consumption in personal rites of passage and identity reconstruction. J Consum Res 1991;17:412-25 (March).

Schouten JW, McAlexander JH. Subcultures of consumption: an ethnography of new bikers. J Consum Res 1995;22:43-61 (June).

Shaw D, Brailsford I. Skeptical Shoppers: an exploration of consumer empowerment, past and present presented at Symposium on Anticonsumption, Auckland, NZ; 2006. June.

Shih M, Pittinsky TL, Ambady N. Stereotype susceptibility: identity salience and shifts in quantitative performance. Psychol Sci 1999;10(1):130-55.

Simmel G. Conflict and the Web of Group Affiliations. New York: Free Press; 1955.

Sirgy MJ. Self-concept in consumer behavior: a critical review. J Consum Res 1982;9(December):287-300.

Sirgy MJ, Grewal D, Mangleburg TF, Park J, Chon KS, Claiborne CB, et al. Assessing the predictive validity of two methods of measuring self-image congruence. J Acad Mark Sci 1997;25(3):229-41.

Smelser NJ. The rational and the ambivalent in the social sciences: 1997 presidential address. Am Sociol Rev 1998;63:1-16 (Feb).

Sobh R, Lee C, Vaughan G. Feedback Valence and Consumer Motivation: The Moderating Effects of Positive and Negative Reference Values in SelfRegulation. In: Gregory G, Davis T, Craig-Lees M, editors. Asia-Pacific Advances in Consumer Research. Duluth MN: Association for Consumer Research; 2006. p. 287-8.

Solomon MR. The role of products as social stimuli: a symbolic interactionism perspective. J Consum Res 1983;10:319-29 (December).

Steglich C, Snijders TAB, Pearson M. Dynamic networks and behavior: separating selection from influence. Working paper. Groningen: Interuniversity Center for Social Science Theory and Methodology; 2004.

Tajfel H. Social stereotypes and social groups. In: Turner John C, Giles Howard, editors. Intergroup Behaviour. Oxford: Blackwell; 1981. p. 144-67.

Thompson CJ. Caring consumers: gendered consumption meanings and the juggling lifestyle. J Consum Res 1996;22:388-407 (March).

Thompson CJ, Haytko DL. Speaking of fashion: consumers' uses of fashion discourses and the appropriation of countervailing cultural meanings. J Consum Res 1997;24:15-42 (June).

Tian K, Belk RW. Extended self and possessions in the workplace. J Consum Res 2005;32:297-310 September. 
White K, Dahl DW. To be or not be? The influence of dissociative reference groups on consumer preferences. J Consum Psychol 2006;16(4): 404-14.

Wilk RR. I hate Pizza: Distaste and Dislike in the Consuming Lives of Belizeans, American Anthropological Association Meeting, Atlanta; 1994. November.
Wilk RR. Learning Distaste: The Social Importance of Not-Wanting, conference paper read at "Learning to Consume". Lund University; 1995. August.

Wilk RR. A critique of desire: distaste and dislike in consumer behavior. Consump Mark Cult 1997;1(2):175-96.

Wood JV. Theory and research concerning social comparisons of personal attributes. Psychol Bull 1989;106:231-48 September. 